\title{
The Market as Institutionalization of Irresponsibility: An Ethical Reflection on Free Market Capitalism
}

\author{
Dante A Urbina* \\ Faculty of Business and Economics, University of Lima, Peru
}

Submission: January 23, 2020; Published: January 28, 2020

"Corresponding author: Dante A Urbina, Professor at the Faculty of Business and Economics, University of Lima, Peru

Abstract

This article is an ethical reflection on free market capitalism. It is maintained that the buyer-seller dynamics is based on and also generates selfish individuals who tend to forget the moral dimension of their actions in the market. The price system plays an important role in this respect since it eliminates qualitative differences among goods. The alleged moral justification of capitalism by appealing to liberty is also called into question

Keywords: Capitalism; Free market; Ethics

\section{Opinion}

In his opening lecture Nassau Senior, renowned British economist and first professor of political economy at the University of Oxford, said: "The pursuit of wealth is, to the mass of mankind, the great source of moral improvement" [1]. Whether we like it or not, Senior's view is still present in the current thinking. For instance, on February 1994 an editorialist of The Economist wrote: "Capitalism is a kind of freedom. Give people some rights (such as the property right and the right to sell their own workforce) and leave them on their own, and you get capitalism. Capitalism is a good thing especially because freedom is a good thing" [2].

Such statements lead us to ask ourselves: Is it true that the mere free market generates moral improvement? To answer this question, it is necessary to understand how the market works. Basically, the market is a system in which buyers and sellers come together in order to buy and sell goods and services. One is only responsible for oneself. Individuals act in a rational way (i.e., egoistically) making decisions "at the margin," that is, without considering all the consequences of their actions but only the additional benefit derived from buying or selling an additional unit of a good or service.

In this way, the buyer is a "bargain hunter." The origin of the goods or the circumstances in which they were produced are not relevant since buyers are only interested in making the best investment in order to satisfy their tastes and preferences. So, it would be "irrational" to pay extra price just because the seller is poor or because one suspects that a particular merchandise is very cheap due to it was produced under conditions of labor exploitation. On the other hand, the seller is a "buyers hunter." Sellers worry about the quality or appropriateness of their product only to the extent that it can affect their future sales, undermine their competitiveness or cause them to be punished by law. The seller has to convince buyers that they need his products even if they don't because profits is the only thing that he cares about. This is why advertising has become so important in the current phase of capitalism. So, everyday millions of children, youth and adults see men and women promoting all kinds of merchandises (food, cellphones, cars, etc.) with excessive enthusiasm. However, does this advertising transmit an ethical message? Does it show "real" people who talk with conviction about things that they really belief?

Let us consider the price system. By virtue of the quantitative price system, all qualitative differences among goods are suppressed. Money -what Marx called "the universal whore" [3]is the common measure to which all is reduced in the capitalist society. Each thing can be measure in terms of other things. This 
is the empire of the quantity. The value is the same thing that the price. Love, truth and beauty can only survive in the market if they generate profits. In fact, market efficiency is based to a great extent on the fact that the dynamics of markets makes us forget the moral dimension of our economic actions. But this moral dimension is still there. So, for instance, in examining whether it is lawful to sell a thing for more than its worth, Aquinas says that "if either the price exceed the quantity of the thing's worth, or, conversely, the thing exceed the price, there is no longer the equality of justice: and consequently, to sell a thing for more than its worth, or to buy it for less than its worth, is in itself unjust and unlawful" [4].

Thus, the market is not an automatic mechanism of moral improvement. On the contrary, it seems that it has become a sort of institutionalization of irresponsibility. We must see markets as what they really are: economically efficient structures but highly dubious guides for our moral behavior. For this reason, we must fight against the merchantalization of all our life. We cannot permit that our market economy generates a market society or, in the words of R. H. Tawney, an "acquisitive society" [5] in which everything may be bought and sold, thus creating cynical individuals who know the price of everything and the value of nothing.

In fact, the moral justification of capitalism in the name of "liberty" is not only illusory but also pernicious because, as Marcuse notes, "liberty can be made into a powerful instrument of domination" [6]. In reality, we are not "free to choose." On the contrary, every day our needs and preferences are manipulated by the economic and political interests of our society. In this way, as Urbina says, "the supposed 'sovereignty' of the consumer is, to say the least, clearly undermined in the present context of the technological society, the propagation and influence of the communication media, the development of publicity, the sales strategies, the planning system and the predominance of oligopoly and monopoly market structures. [...] Only a fool could think that the objective of the advertisement is solely informative when the overwhelming evidence shows us that it is essentially persuasive. [...] The single fact that the needs of the consumers are being continuously manipulated and exacerbated by advertisement and sales techniques demonstrates that their preferences are not completely autonomous" [7]

This is how neoliberal capitalism, by making us believe that we are free, makes us slaves of the market, thus eliminating the possibility of thinking of another world. But the TINA ("There is no alternative") slogan is nothing more than a fallacy. It is true that communism is not a viable alternative, nor is it desirable. But, contrary to Fukuyama's view [8], the "end of history" has not yet come. History is not over, and neoliberal capitalism must not be considered as the best possible world because another world is not only possible but also necessary.

\section{References}

1. Senior N (1827) Introductory Lecture on Political Economy. Oxford, UK.

2. de Gaay Fortman B, Klein Goldewijk B (1998) God and the Goods: Global Economy in a Civilizational Perspective. WWC Publications, Geneva, Switzerland.

3. Marx K (1844) Economic and Philosophic Manuscripts. Third Manuscript.

4. Aquinas T (1274) Summa Theologiae. II-IIae q. 77.

5. Tawney RH (1920) The Acquisitive Society. Harcourt, Brace and Howe, New York, USA.

6. Marcuse H (1964) One-Dimensional Man. Beacon, Boston, USA.

7. Urbina DA (2019) Economics for Heretics: Debunking the Myths of Orthodox Economics. KDP, Seattle, chapter 6, USA.

8. Fukuyama F (1992) The End of History and the Last Man. The Free Press, New York, USA.

\begin{tabular}{l} 
Your next submission with Juniper Publishers \\
will reach you the below assets \\
- Quality Editorial service \\
- Swift Peer Review \\
- Reprints availability \\
- E-prints Service \\
- Manuscript Podcast for convenient understanding \\
- Global attainment for your research \\
- Manuscript accessibility in different formats \\
( Pdf, E-pub, Full Text, Audio) \\
- Unceasing customer service \\
Track the below URL for one-step submission \\
https://juniperpublishers.com/online-submission.php \\
\hline
\end{tabular}

